\title{
Comparative cytogenetics of Astyanax (Teleostei: Characidae) from the upper Paraguay basin
}

\author{
Thais K. S. S. Teixeira ${ }^{1}$, Paulo C. Venere ${ }^{1}$, Daniela C. Ferreira ${ }^{1}$, Sandra Mariotto $^{2}$, \\ Jonathan P. Castro ${ }^{3}$, Roberto F. Artoni ${ }^{3,4}$ and Liano Centofante ${ }^{1}$
}

Astyanax is one of the most abundant and diverse taxa of fishes in the Neotropical region. In order to increase the amount of cytogenetic information for Astyanax as well as to exhibit data to subsidize future taxonomic studies, this work analyzed three species of Astyanax: two species are cryptic, and are here reported to live in syntopy (A. abramis and A. lacustris); the first karyotype description for A. pirapuan is also presented. Cytogenetic analyzes reveal a diploid number of $2 \mathrm{n}=50$ chromosomes for three species, yet with differences in their karyotype morphology. The physical mapping of 18S rDNA showed up to thirteen sites in A. pirapuan and two in A. abramis and A. lacustris. The physical mapping of 5S rDNA has proven to be an effective marker for the characterization of species of Astyanax studied in this work.

Keywords: Cryptic species, Fish, Karyotype, Species complex.

Astyanax é um dos táxons mais representados e diversos na região Neotropical. Com o intuito de aumentar as informações citogenéticas para Astyanax e apresentar dados que possam subsidiar estudos taxonômicos futuros, este trabalho traz uma análise citogenética de três espécies de Astyanax: duas espécies consideradas crípticas, aqui reportadas em sintopia (A. abramis e $A$. lacustris) e a primeira descrição cariotípica de $A$. pirapuan. As análises citogenéticas revelaram $2 \mathrm{n}=50$ cromossomos para as três espécies, com diferença na morfologia cariotípica de cada uma. Foram observados apenas dois sítios de rDNA $18 \mathrm{~S}$ em A. abramis e A. lacustris e até 13 para A. pirapuan. O mapeamento físico do rDNA 5S se mostrou como um marcador efetivo para a caracterização das espécies de Astyanax abordadas neste estudo.

Palavras-chave: Cariótipo, Complexo de espécies, Espécies crípticas, Peixe.

\section{Introduction}

Astyanax is the most widely distributed and locally abundant genera living in Neotropical freshwaters (Buckup et al., 2007); composed of 155 valid species (Eschmeyer, Fong, 2016) from which 30 were described in the past decade. Six species are reported in the Paraguay basin: Astyanax lineatus, A pellegrini, A. marionae, A. lacustris (=A. asuncionensis), A. abramis (Britski et al., 2007) and A. pirapuan (Tagliacollo et al., 2011).

Owing to the similarity between the morphological characteristics of Astyanax, many are considered as cryptic species in which some groups are classified as species complexes because of their taxonomy, as is the case for the "Astyanax bimaculatus" complex is which typically shows a horizontally oval black humeral spot, two vertical brown bars, and a black spot in the caudal peduncle that extends onto the caudal fin rays (Garutti, Britski, 2000; Garutti, Langeani, 2009). The "Astyanax scabripinnis" complex characterized by having a robust body close to the pectoral fins, massive head, short snout, and a lower number of anal-fin rays (Bertaco, Lucena, 2006).

After taxonomic review of species "Astyanax bimaculatus" complex, Lucena, Soares (2016) validates $A$. abramis (Jenyns, 1842), and argues that $A$. asuncionensis Géry, 1972 and A. altiparanae Garutti \& Britski, 2000 are synonyms of $A$. lacustris (Lütken, 1875).

\footnotetext{
${ }^{1}$ Universidade Federal de Mato Grosso, Av. Fernando Correa da Costa S/N, Coxipó, 78068-900 Cuiabá, MT, Brazil. (TKSST) thaisteixeiraa2@hotmail.com, ○https://orcid.org/0000-0003-1343-9736 (corresponding author), (PCV) pvenere@uol.com.br, (DCF) ferreiradc@gmail.com,(LC) lianocentofante@yahoo.com.br

${ }^{2}$ Instituto Federal de Educação, Ciência e Tecnologia de Mato Grosso (IFMT), Campus Cuiabá - Bela Vista, Avenida Juliano Costa Marques s/n Bela Vista, 78050-560 Cuiabá, MT, Brazil. sandra.mariotto@blv.ifmt.edu.br

${ }^{3}$ Programa de Pós-Graduação em Genética Evolutiva e Biologia Molecular, Departamento de Genética e Evolução, Universidade Federal de São Carlos, Rodovia Washington Luis, Km 235, Monjolinho, 13565-905 São Carlos, SP, Brazil. (JPC) jonathan.penacastro@gmail.com, (RFA) rfartoni@gmail.com

${ }^{4}$ Departamento de Biologia Estrutural, Molecular e Genética, Universidade Estadual de Ponta Grossa. Av. Carlos Cavalcanti, 4748, 84030900 Ponta Grossa, PR, Brazil.
} 
Cytogenetic studies on Astyanax were stimulated by the work of Jim, Toledo (1975). Several contributions have been made to the study of this group so far that show that, among other characteristics, this genus exhibits a high variability in its diploid number that varies from $2 \mathrm{n}$ $=36$ chromosomes in A. schubarti and A. correntinus to $2 \mathrm{n}=52$ chromosomes in Astyanax sp. (Tenório et al., 2013). However, the diploid number of $2 \mathrm{n}=50$ chromosomes is the most frequent for representatives of genus (reviewed from Pazza, Kavalco, 2007).

The term 'species complex' was first used by MoreiraFilho, Bertollo (1991) for describing cryptic species of A. scabripinnis. The study showed that populations of this species had different diploid numbers $(2 n=46,2 n=48$ and $2 \mathrm{n}=50$ ). Two other complexes, Astyanax fasciatus and $A$. bimaculatus, were also differentiated on the basis of cytogenetic data The former has a diploid number varying from $2 \mathrm{n}=45$ to $2 \mathrm{n}=50$ chromosomes (Artoni et al., 2006; Pazza et al., 2006), and the latter a relatively constant diploid number, yet showing differences in the karyotype composition with variable fundamental numbers (FN) from 76 to 100 (Fernandes, Martins-Santos, 2004).

Species complexes in Asytanax have been intensely studied not only regarding the number and morphology of chromosomes, but also regarding other cytogenetic markers. The mapping of ribosomal gene sequences (rDNA 18S and rDNA5S) by the technique of fluorescence in situ hybridization (FISH) has proven to be effective in characterizing species as well as understanding their chromosomal evolution (Mantovani et al., 2005; Fernandes, Martins-Santos, 2006a, 2006b; Kavalco et al., 2011; Paiz et al., 2015; among others).

The location of the 18S rDNA gene is not constant in Astyanax, varying from two sites as is the case for A. lacustris, A. abramis, $A$. argyrimarginatus and $A$. asuncionensis up to seven sites in populations of $A$. altiparanae; all these species are part of the "Astyanax bimaculatus" complex (Fernandes, Martins-Santos, 2006a; Peres et al., 2008; Ferreira-Neto et al., 2009; Tenório et al., 2013; Paiz et al., 2015). In the "Astyanax scabripinnis" complex, 13 sites were observed for this gene in A. paranae, and 16 sites in A. scabripinnis (Mantovani et al., 2005; Vicari et al., 2008a). The 5S rDNA gene, in turn, has shown through the FISH technique variable markings on two sites in A. altiparanae, A. lacustris, and A. asuncionensis (Fernandes, Martins-Santos, 2006a; Peres et al., 2008; Paiz et al., 2015) and on four sites in $A$. argyrimaginatus and $A$. abramis (Tenório et al., 2013; Paiz et al., 2015). Four sites are observed in $A$. paranae and $A$. scabripinnis (Mantovani et al., 2005; Vicari et al., 2008a). Although this subject still requires further review, the fact is that in situ location of ribosomal sequences may be a valuable tool for helping on the - systematics of Astyanax given their variation in location on the chromosomes of this group.

In order to increase the cytogenetic information for Astyanax and to produce data that may support future taxonomic studies, the present work is an integrative (cytogenetic, morphological and molecular) study with three species from the upper Paraguay basin. The karyotypic description of A. pirapuan Tagliacollo, Britzke, Silva \& Benine, 2011 (belonging to the "Astyanax scabripinnis complex") are reported for the first time and a comparative study of the cryptic species A. lacustris and A. abramis (belonging to the "Astyanax bimaculatus complex") that occur in syntopy are also reported.

\section{Material and Methods}

The 122 specimens of Astyanax analyzed were collected from three streams that are part of the upper Paraguay basin in the Brazilian state of Mato Grosso: Soberbo

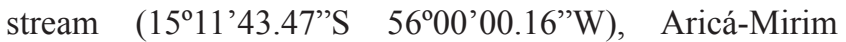

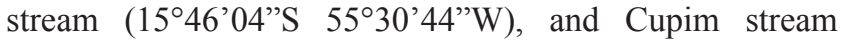
$\left(15^{\circ} 52^{\prime} 24.30^{\prime \prime} \mathrm{S} 55^{\circ} 28^{\prime} 00.35^{\prime \prime} \mathrm{W}\right)$. Voucher specimens were deposited in the Coleção de Peixes da Universidade Federal de Mato Grosso (voucher numbers: CPUFMT 4431-4438).

Chromosomal studies were carried out on 10 female samples and one male sample of Astyanax lacustris, 12 females and six males of $A$. abramis from the Soberbo stream as well as on the populations of $A$. pirapuan, 37 females and 16 males from the Aricá-Mirim stream, and 30 females and 10 males from the Cupim stream.

The identification of the specimens was performed following Britski et al. (2007) and Tagliacollo et al. (2011), which describes $A$. pirapuan. The three species analyzed in this work are: A. abramis, A. lacustris and A. pirapuan (Fig. 1).

Mitotic chromosomes were obtained through the technique of cell suspension, which is routinely used for chromosomal studies on fishes (Bertollo et al., 1978). The identification of constitutive heterochromatin was carried out through the technique of C-banding according to Sumner (1972) and the characterization of nucleolus organizer regions (Ag-NORs) was performed using the technique described by Howell, Black (1980).

The technique applied for mapping ribosome sites was fluorescence in situ hybridization using $5 \mathrm{~S}$ and $18 \mathrm{~S}$ rDNA probes in agreement with the protocol established by Pinkel et al. (1986), and later modified by Martins, Galetti Júnior (2001).

The determination of the diploid number in each species was performed through the counting of 30 metaphases per specimen. The best metaphases were photographed using an Olympus BX51 microscope, and the digital mounting of karyotypes was performed using the Pro Image software according to the classification of chromosomal types into metacentric (m), submetacentric (sm), subtelocentric (st) and acrocentric (a) on the basis of arm ratio as proposed by Levan et al. (1964), with some adjustment to fishes and for determination of the fundamental number (NF), the metacentric,submetacentric and subtelocentric chromosomes were considered biarmed, and the acrocentric uniarmed. 


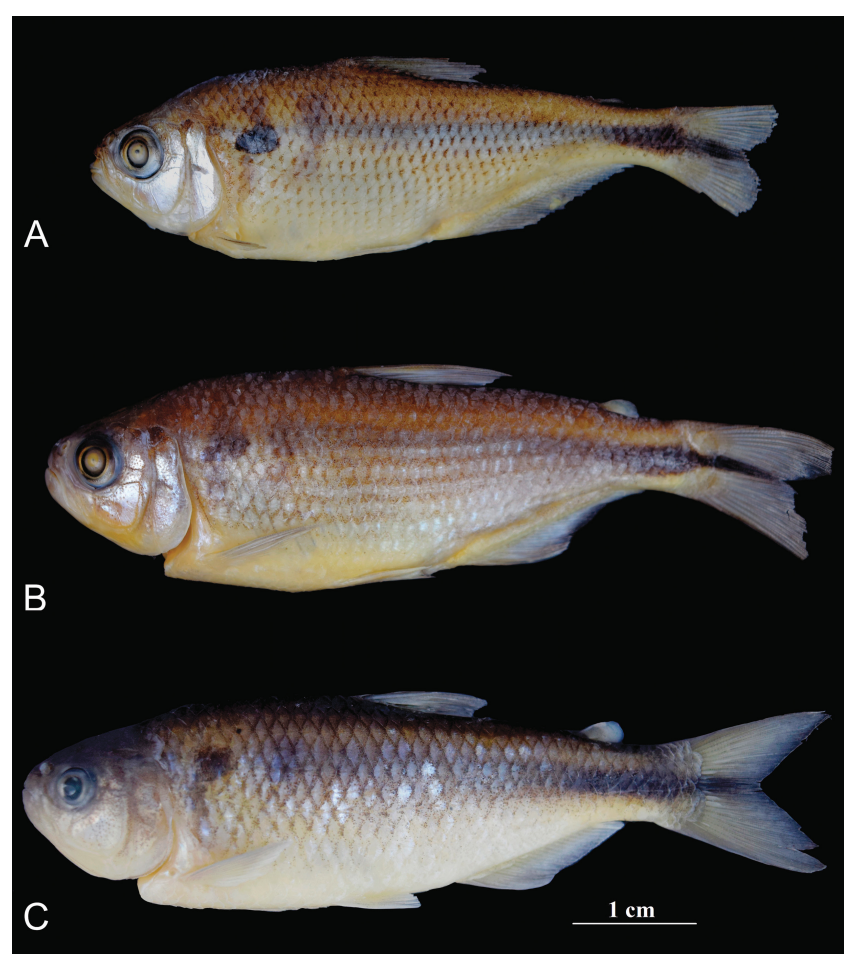

Fig. 1. Astyanax abramis - voucher number CPUFMT 4437 Soberbo stream (A), Astyanax lacustris - voucher number CPUFMT 4436 Soberbo stream (B) and Astyanax pirapuan - voucher number CPUFMT 4433 Cupim stream (C).

\section{Results}

All three species of Astyanax have the same modal diploid number of $2 \mathrm{n}=50$ chromosomes. Their karyotypes formulas can be summarized as $6 \mathrm{~m}+10 \mathrm{sm}+18 \mathrm{st}+16 \mathrm{a}$ and $\mathrm{NF}=84$ for A. lacustris, $8 \mathrm{~m}+10 \mathrm{sm}+26 \mathrm{st}+6 \mathrm{a}$ and $\mathrm{NF}=$ 94 for A. abramis, and $6 \mathrm{~m}+14 \mathrm{sm}+14 \mathrm{st}+16 \mathrm{a}$ and $\mathrm{NF}=$ 84 for both populations of $A$. pirapuan (Figs. 2A,C,E). Heteromorphic sex chromosomes were not detected.

In A. lacustris and A. abramis, simple Ag-NORs sites were observed in the terminal region of the short arm of subtelocentric chromosome pairs 13 and 11, respectively (Figs. 2A,C - Box). On the other hand, A. pirapuan showed markings on chromosomes one to four, and up to six markings on interphase nucleus. The Ag-NOR were observed in -terminal region of the -short arm of chromosomes 11 and 13. It should be highlighted that three individuals of the population from the Cupim stream presented bitelomeric markings on one of the homologous of chromosome pair 13. In addition, the acrocentric pairs 19 and 22 showed Ag-NORs also in the terminal region of the -short arm and long arm, respectively, in only one of the homologous (Fig. 2E - Box).

Blocks of constitutive heterochromatin are mainly observed in A. lacustris on pericentrometric regions of the metacentric chromosomes one and two, submetacentric chromosome six, and acrocentric chromosomes 23 and 25 . A prominent marking was observed on the short arm of the subtelocentric chromosome 13 (Fig. 2B), which is coincident with the Ag-NORs. Astyanax abramis has karyotypes with low heterochromatin content, which are more specifically localized at the interstitial region of chromosome pair one, in the short arm of the subtelocentric chromosome pair 11 which coincides with the Ag-NORs, pericentrometric regions of subtelocentric chromosome pairs 14,16 and 17 , centrometric regions of chromosome pairs 10, 13, 19, 20 and 22 as well as in the pericentrometric and telomeric regions of acrocentric pairs 23 and 25 (Fig. 2D).

Both the populations of $A$. pirapuan have clearly visible constitutive heterochromatin at the pericentrometric regions of the chromosome pairs 3, 4, 5, 7, 13, 15,16, $18,20,22,23,24$ as well as in the interstitial position of the long arm of pair 1; conpiscuous telomeric blocks occurs on the long and short arms of chromosome pairs 11 and 13, respectively, coinciding with regions bearing Ag-NORs sites (Fig. 2F). The chromosome pair 11 shows polymorphism of heterochromatinin in both populations. Some fishes have heterochromatin in their telomeric regions of the long arm, however others have heterochromatin only in one of the homologous. Furthermore, in places, similar blocks are found on the short arm of whether both chromosomes of pair 11 or only in one of the homologous. Moreover, no heterochromatin blocks were found in some specimens. It is worth mentioning that this condition is accompanied by the presence of $18 \mathrm{~S}$ rDNA sites in association with heterochromatic regions in this chromosome pair.

The physical mapping of $18 \mathrm{~S}$ rDNA shows markings on two sites in A. lacustris (st number 13), and in $A$. abramis (st number 11) that coincides with Ag-RONs (Figs. 2AC - Box). Astyanax pirapuan revealed variation both in the amount (4 to 13 sites) and the position of $18 \mathrm{~S}$ rDNA in chromosomes (Fig. 3) of individuals from both locations studied. However, despite the variability shown, some markings are constant in the telomeric region of the long arm in chromosomes 11 and 12, and in the telomeric regions of the short arm of pairs 13, 19, 21 and 23. A peculiar feature is that three specimens from the Cupim stream showed bitelomeric Ag-NORs in only one of the homologous of the subtelocentric chromosome pair 13 as confirmed by FISH using an $18 \mathrm{~S}$ rDNA probe (Fig. 3).

The $5 \mathrm{~S}$ rDNA sites are found in the pericentrometric region of submetacentric chromosome six in A. lacustris (Fig. 4A) as well as in this same position of the following chromosome pairs: submetacentric six, subtelocentric 13, and acrocentric 24, which results in six sites in $A$. abramis (Fig. 4B). On the other hand, the populations of A. pirapuan showed sites in the pericentrometric region of chromosome pair 16, for both populations and acrocentric pair 18 - presented 2 sites a pericentromeric and another interstitial to Cupim stream population and interstial for the population Aricá-Mirim stream (Figs. 4C,D). 
A

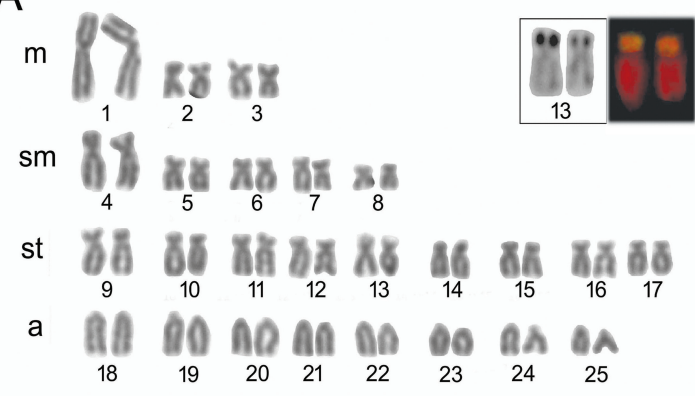

C

$\mathrm{m}$

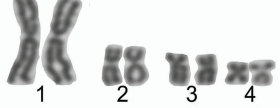

$\mathrm{sm}$

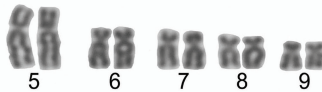

st

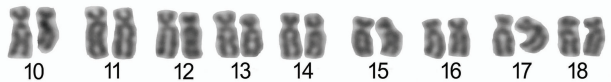

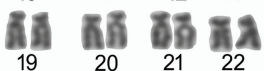

a

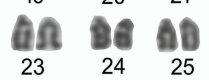

$E$

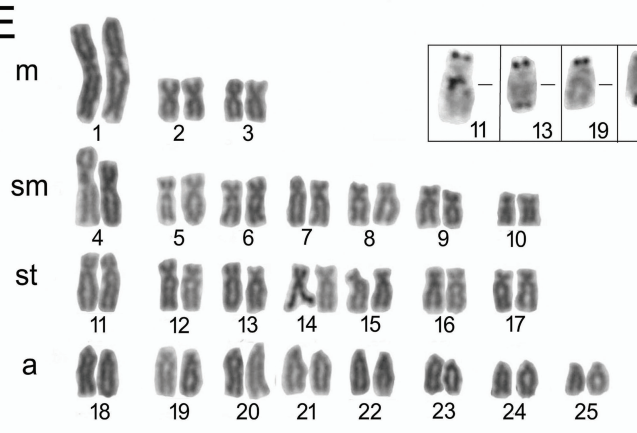

B

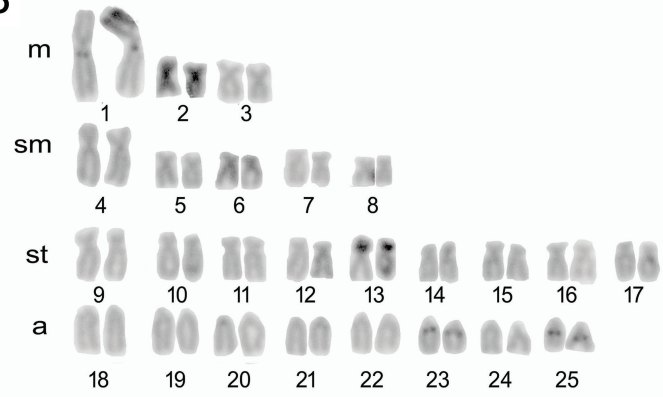

D

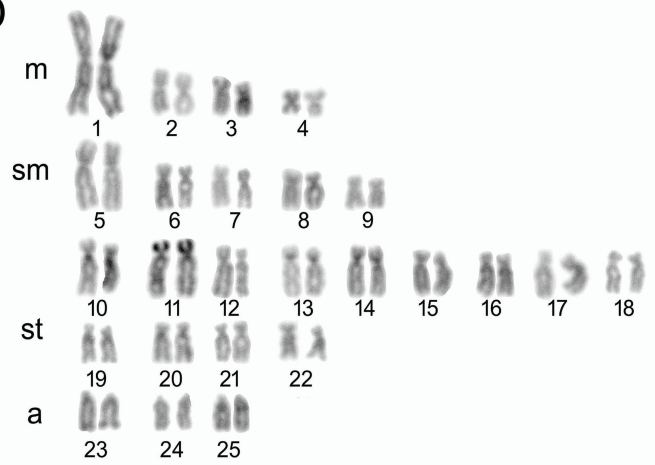

$\mathrm{F}$

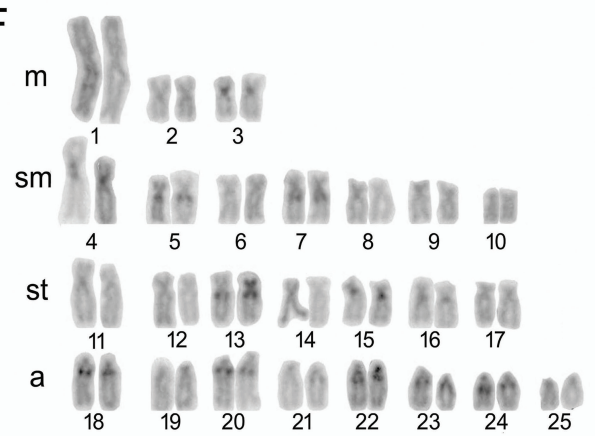

Fig. 2. Karyotypes of Astyanax abramis (A and $\mathbf{B})$, A. lacustris (C and $\mathbf{D})$ and A. pirapuan $(\mathbf{E}$ and $\mathbf{F})$ after Giemsa-stained and showing the distribution of constitutive heterochromatin revealed by C-banding. Insets show Ag-NOR and 18S-bearing chromosomes pairs. Scale bar $=10 \mu \mathrm{m}$.

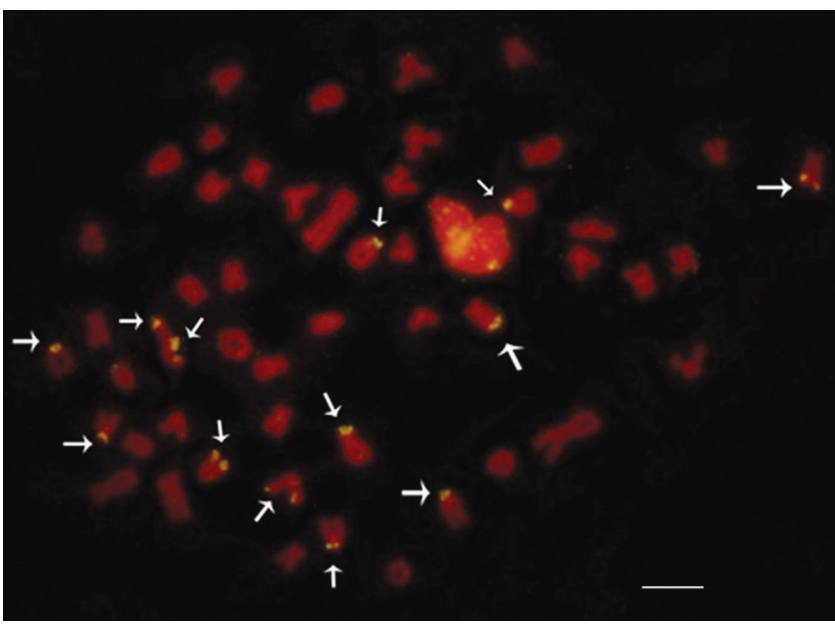

Fig. 3. Metaphase of Astyanax pirapuan after fluorescent in situ hybridization with $18 \mathrm{~S}$ probe. Arrows indicate the marked chromosomes. Scale bar $=10 \mu \mathrm{m}$.

\section{Discussion}

Garutti, Britski (2000), and Bertaco, Garutti (2007) described many species of Astyanax to the "Astyanax bimaculatus" species complex, which comprises several cryptic species that have a close phylogenetic relationship (Garutti, Langeani, 2009). Astyanax lacustris and A. abramis are attributed to that complex in this work, and are distinguished by their number of perforated lateral-line scales.

The review of Lucena, Soares (2016) elaborated on the basis of morphological characters establishes that the number of scales for A. abramis varies from 42 to 49 while this number varies from 36 to 39 for $A$. lacustris, although rare individuals are known to have from 40 to 41 scales. In the present work the perforated lateral-line scales were counted from specimens of A. lacustris and A. abramis. We noted variation in number from 33 to 40 scales, and from 35 to 43 scales, respectively. 


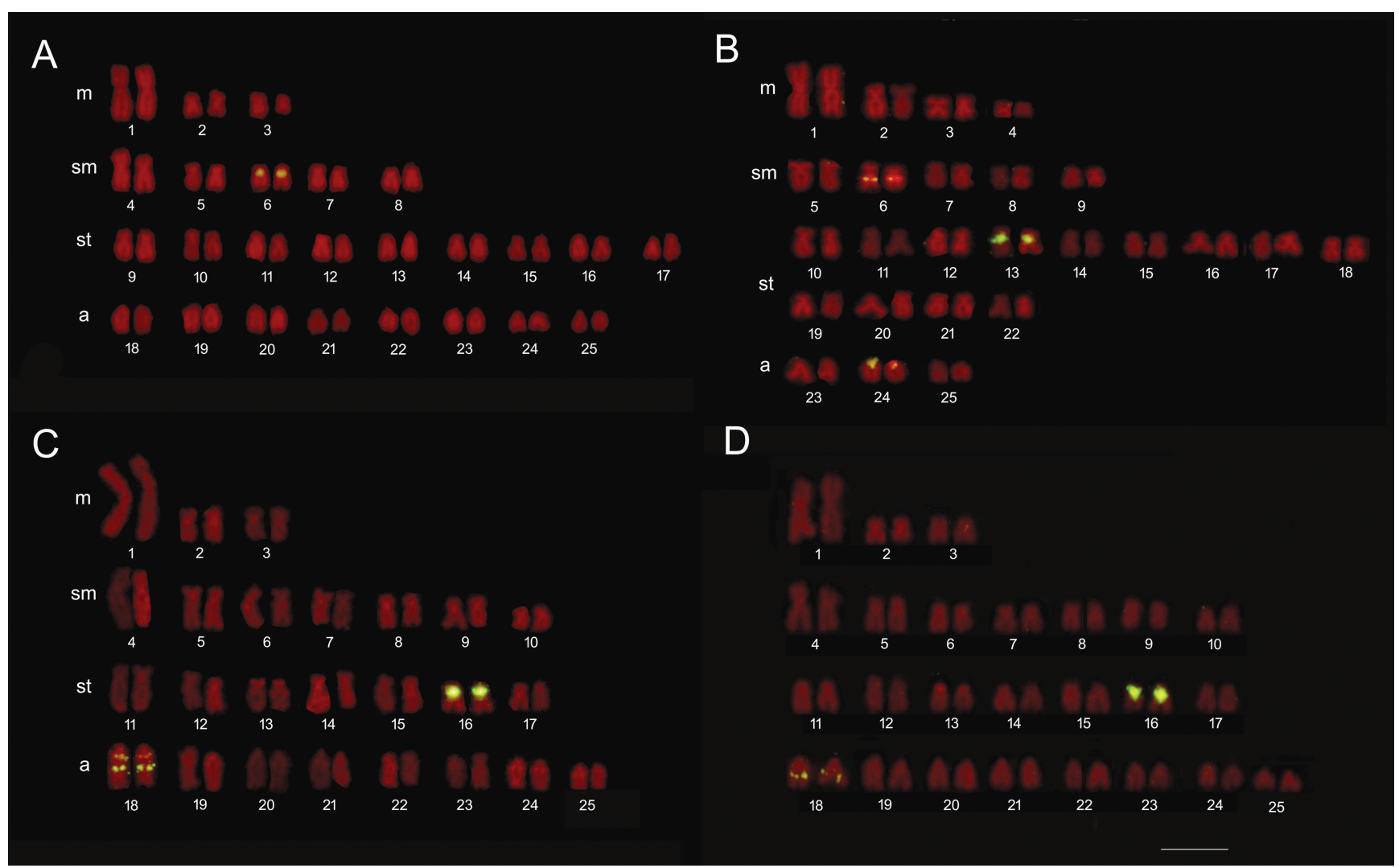

Fig. 4. Karyotypes of Astyanax abramis (A), A. lacustris (B) and A. pirapuan from Cupim stream $(\mathbf{C})$ and Aricá stream (D) after fluorescent in situ hybridization with $5 \mathrm{~S}$ probe. Scale bar $=10 \mu \mathrm{m}$.

However, A. lacustris and A. abramis show cytotaxonomic features considered as species-specific with single patterns for each one of them. Although they present the same chromosome number, $A$. lacustris have a higher number of acrocentric chromosomes (16 chromosomes) than $A$. abramis (six chromosomes), which influence on their fundamental numbers ( 84 and 94 , respectively).

The chromosomal location of ribosomal genes helps in the understanding of the evolutionary history of Astyanax. The 18S rDNA sites are simple both for lacustris and A. abramis as well positioned in both species in a subtelocentric chromosome pair, which is likely homeologous. Several species of Astyanax share at least a common pair of subtelocentric chromosomes with markings of Ag-NORs/18S in telomeric region of short arm both for species with simple Ag-NORs (Fernandes, Martins-Santos, 2006a; Domingues et al., 2007; Peres et al., 2008; Peres et al., 2012; Barbosa et al., 2015) and those with multiple systems (Domingues et al., 2007; Vicari et al., 2008b; Kavalco et al., 2011; Silva et al., 2012; Tenório et al., 2013; Castro et al., 2015). That demonstrates that this subtelocentric chromosome pair and its location pattern for Ag-NORs may represent an ancestral condition for Astyanax.

The physical mapping of 5S rDNA is an effective marker for the characterization of $A$. lacustris (two sites) and $A$. abramis (six sites). When comparing this marker behavior to other populations of these two same species, we observe that the number of 5S rDNA sites for A. lacustris remains unchanged (Fernandes, Martins-Santos, 2006a; Domingues et al., 2007; Peres et al., 2008; Ferreira-Neto et al., 2009; Kavalco et al., 2011; Paiz et al., 2015). On the other hand, the population of $A$. abramis collected from the lower Paraná Basin presented only four sites (Paiz et al., 2015). Among the species of the "Astyanax bimaculatus" complex studied so far, only A. abramis and A. argyrimarginatus (Tenório et al., 2013) have more than two sites (four markings) of 5S rDNA.

Here, we present the first description of the karyotype of A. pirapuan ("Astyanax scabripinnis" complex) for the Paraguay basin. Populational differences were here highlighted once the population from the Cupim stream may be distinguished by two markings of $5 \mathrm{~S}$ rDNA on the same arm of the chromosome pair 18 , which is usually observed in the homozygous state. This same population shows a polymorphism related to the $18 \mathrm{~S}$ rDNA sites where some individuals have bitelomeric markings in one of the subtelocentric chromosome pair 13.

In addition, two populations of $A$. pirapuan presented an intra-populational variation in the number of $18 \mathrm{~S}$ rDNA sites (four to 13 sites). Mantovani et al. (2005) also observed an intra-populational variation in $18 \mathrm{~S}$ rDNA sites for populations of $A$. scabripinnis from the Paraná and São Francisco basins where up to 16 sites are reported. This condition is common for representatives of the "Astyanax scabripinnis" complex (Ferro et al., 2000; Mantovani et al., 
2005; Fernandes, Martins-Santos, 2006b), likely facilitated both by their telomeric position in chromosomes, which makes them more susceptible to chromosomal rearrangement (Mantovani et al., 2005) as well as to associations with transposable elements as is the case for A. bockmanni (Silva et al., 2013).

Opposite of what is observed in most of the species belonging to the "Astyanax scabripinnis" complex with respect to heterochromatic regions, A. pirapuan shows low heterochromatin content restricted to pericentrometric regions including the presence of small interstitial blocks in some chromosomes. An outstanding feature for most species of the "Astyanax scabripinnis" complex is the occurrence of conspicuous heterochromatic blocks, mainly in acrocentric chromosomes (Moreira-Filho, Bertollo 1991; Maistro et al., 1998; Souza, Moreira-Filho, 1995; Mizoguchi, MartinsSantos, 1998; Mantovani et al., 2000; Souza et al., 2007; Tenório et al., 2013). The one exception is a population of A. laticeps that has a few heterochromatic regions in the karyotype (Rosa et al., 2009). Some cases are followed by heterochromatic polymorphism on subtelocentric to acrocentric chromosomes (Mantovani et al., 2000; Souza et al., 2007) as it is observed in the chromosome pair 11 in $A$. pirapuan.

The data presented in this work show valuable contributions to the cytogenetic studies in the genus Astyanax. The karyotype of A. pirapuan is described for the first time and corroborates with data already described for most species of the genus. Reinforcing the constant number of chromosomes $2 \mathrm{n}=50$ with distribution specific for most species. The variation found in the sites for the $18 \mathrm{~S}$ rDNA reinforces a greater relation of this group with "Astyanax scabripinnis" complex. Astyanax pirapuan may be distinguished from other species of the A. scabripinnis complex by its karyotype formulae, position of $18 \mathrm{~S}$ and $5 \mathrm{~S}$ rDNA sites, and low heterochromatin content (except for A. laticeps).

\section{Acknowledgments}

The authors are grateful to Fundação de Amparo a Pesquisa do Estado do Mato Grosso (FAPEMAT) for financial support.

\section{References}

Artoni RF, Shibatta OA, Gross MC, Schneider CH, Almeida MC, Vicari MR, Bertollo LAC. Astyanax aff. fasciatus Cuvier, 1819 (Teleostei; Characidae): evidences of a species complex in the upper rio Tibagi basin (Paraná, Brazil). Neotrop Ichthyol. 2006; 4(2):197-202.

Barbosa P, Oliveira LA, Pucci MB, Santos MH, Moreira-Filho O, Vicari MR, Nogaroto V, de Almeida MC, Artoni RF. Identification and chromosome mapping of repetitive elements in the Astyanax scabripinnis (Teleostei: Characidae) species complex. Genetica. 2015; 143(1):55-62.
Bertaco VA, Garutti V. New Astyanax from the upper rio Tapajós drainage, Central Brazil (Characiformes: Characidae). Neotrop Ichthyol. 2007; 5(1):25-30.

Bertaco VA, Lucena CAS. Two new species of Astyanax (Ostariophysi: Characiformes: Characidae) from eastern Brazil, with a synopsis of the Astyanax scabripinnis species complex. Neotrop Ichthyol. 2006; 4(1):53-60.

Bertollo LAC, Takahashi CS, Moreira-Filho O. Cytotaxonomic considerations on Hoplias lacerdae (Pisces, Erythrinidae). Braz J Genet. 1978; 1:103-20.

Britski HA, Silimon KZS, Lopes BS. Peixes do Pantanal: Manual de identificação. Brasília: Embrapa; 2007.

Buckup PA, Menezes NA, Ghazzi MS. Catálogo das espécies de peixes de água doce do Brasil. Rio de Janeiro: Museu Nacional; 2007. (Série livros 23).

Castro JP, Moura MO, Moreira-Filho O, Shibatta OA, Santos MH, Nogaroto V, Vicari, MR, Almeida MC, Artoni RF. Diversity of the Astyanax scabripinnis species complex (Teleostei: Characidae) in the Atlantic Forest, Brazil: species limits and evolutionary inferences. Rev Fish Biol Fish. 2015; 25(1):231-44.

Domingues SM, Vicari MR, Abilhoa V, Wamser PJ, Cestari MM, Bertollo LAC, Almeida MC, Artoni RF. Cytogenetic and comparative morphology of two allopatric populations of Astyanax altiparanae Garutti \& Britski, 2000 (Teleostei: Characidae) from upper rio Paraná basin. Neotrop Ichthyol. 2007; 5(1):37-44.

Eschmeyer WN, Fong JD. Species by family/ subfamily in the Catalog of Fishes. [Electronic version]. San Francisco (CA): California Academy of Sciences; 2016. [cited 2016 Jun 17]. Available from: http://researcharchive.calacademy.org/ research/ichthyology/catalog/SpeciesByFamily.asp

Fernandes CA, Martins-Santos IC. Mapping of the $18 \mathrm{~S}$ and 5S ribosomal RNA genes in Astyanax altiparanae Garutti \& Britski, 2000 (Teleostei, Characidae) from the upper Paraná river basin, Brazil. Genet Mol Biol. 2006a; 29(3):464-68.

Fernandes CA, Martins-Santos IC. Chromosomal location of 5S and 18S rRNA genes in three sympatric cytotypes of Astyanax scabripinnis (Characiformes, Characidae) from the Ivaí river basin, state of Paraná, Brazil. Caryologia. 2006b; 59(3):253-59.

Fernandes CA, Martins-Santos IC. Cytogenetic studies in two populations of the Astyanax altiparanae (Pisces, Characiformes). Hereditas. 2004;141(3):328-32.

Ferreira-Neto M, Vicari MR, Camargo EF, Artoni RF, MoreiraFilho O. Comparative cytogenetics among populations of Astyanax altiparanae (Characiformes, Characidae, IncertaeSedis). Genet Mol Biol. 2009; 32(4):792-96.

Ferro DA, Néo DM, Moreira-Filho O, Bertolo LA. Nucleolar organizing regions, $18 \mathrm{~S}$ and $5 \mathrm{~S}$ in Astyanax scabripinnis (Pisces, Characidae): Populations distribution and functional diversity. Genetica. 2000; 110(1):55-62.

Garutti V, Britski HA. Descrição de uma espécie nova de Astyanax (Teleostei: Characidae) da bacia do alto rio Paraná e considerações sobre as demais espécies do gênero na bacia. Comun Mus Ciênc Tecnol, Série Zool. 2000; 13(1):65-88. 
Garutti V, Langeani F. Redescription of Astyanax goyacensis Eigenmann, 1908 (Ostariophysi: Characiformes: Characidae). Neotrop Ichthyol. 2009; 7(3):371-76.

Howell WM, Black DA. Controlled silver-staining of nucleolus organizer region swith a protective colloidal developer: a 1-step method. Experientia. 1980; 36(8):1014-15.

Jim SM, Toledo V. Citogenética de Astyanax fasciatus e Astyanax bimaculatus (Characidae, Tetragonopterinae). Cienc Cult. 1975; 27(1):1122-24.

Kavalco KF, Pazza R, Brandão KO, Garcia C, Almeida-Toledo LF. Comparative cytogenetics and molecular phylogeography in the group Astyanax altiparanae-Astyanax aff. bimaculatus (Teleostei, Characidae). Cytogenet Genome Res. 2011; 134(2):108-19.

Levan A, Fredga K, Sandberg AA. Nomenclature for centromeric position on chromosomes. Hereditas. 1964; 52(2):201-20.

Lucena CAS, Soares HG. Review of species of the Astyanax bimaculatus "caudal peduncle spot" subgroup sensu Garutti \& Langeani (Characiformes, Characidae) from the rio La Plata and rio São Francisco drainages and coastal systems of southern Brazil and Uruguay. Zootaxa. 2016; 4072(1):101-25.

Maistro EL, Foresti F, Oliveira C, Foresti F. Comparative cytogenetic and morphological analysis of Astyanax scabripinnis paranae (Pisces, Characidae, Tetragonopterinae). Genet Mol Biol. 1998; 21(2):201-06.

Mantovani M, Abel LDS, Mestriner CA, Moreira-filho O. Accentuated polymorphism of heterochromatin and nucleolar organizerregions in Astyanax scabripinnis (Pisces, Characidae): tools for understanding karyotype icevolution. Genetica. 2000; 109(3):161-68.

Mantovani M, Abel LDS, Moreira-Filho O. Conserved 5S and variable $45 \mathrm{~S}$ rDNA chromosomal localization revealed by FISH in Astyanax scabripinnis (Pisces, Characidae). Genetica. 2005; 123(3):211-16.

Martins C, Galetti Júnior PM. Two 5S rDNA arrays in Neotropical fish species: is it a general rule for fishes? Genetica. 2001; 111(1-3):439-46.

Mizoguchi SMHN, Martins-Santos IC. Cytogentic and morphometric differences in populations of Astyanax. Genet Mol Biol. 1998; 21(1):55-61.

Moreira-Filho O, Bertollo LAC. Astyanax scabripinnis (Pisces, Characidae): a species complex. Rev Bras Genet. 1991; 14(1):331-57.

Paiz LM, Baumgärtner L, Graça WJ, Margarido VP. Basic cytogenetics and physical mapping of ribosomal genes in four Astyanax species (Characiformes, Characidae) collected in Middle Paraná River, Iguassu National Park: considerations on taxonomy and systematic of the genus. Comp Cytogenet. 2015; 9(1):51-65.

Pazza R, Kavalco KF. Chromosomal evolution in the neotropical characin Astyanax (Teleostei, Characidae). Nucleus. 2007; 50(3):519-43.

Pazza R, Kavalco KF, Bertollo LAC. Chromosome Polymorphism in Astyanax fasciatus (Teleostei, Characidae). 1 - Karyotypic analysis, Ag-NORs and mapping of the $18 \mathrm{~S}$ and $5 \mathrm{~S}$ ribosomal genes in sympatric karyotypes and their possible hybrid forms. Cytogenet Genome Res. 2006; 112(3):313-19.
Peres WAM, Bertollo LAC, Buckup PA, Blanco DR, Kantek DLZ, Moreira-Filho O. Invasion, dispersion and hybridization of fish associated to river transposition: karyotype icevidence in Astyanax bimaculatus group (Characiformes: Characidae). Rev Fish Biol Fish. 2012; 22(2):519-26.

Peres WAM, Bertollo LAC, Moreira Filho O. Physical mapping of the $18 \mathrm{~S}$ and $5 \mathrm{~S}$ ribosomal genes in nine Characidae species (Teleostei, Characiformes). Genet Mol Biol. 2008; 31(1):222-26.

Pinkel D, Straume T, Gray JW. Cytogenetic analysis using quantitative, high sensitivity, fluorescence hybridization. Proc Natl Acad Sci USA. 1986; 83(9):2934-38.

Rosa R, Rubert M, Malabarba LR, Martins-Santo IC, GiulianoCaetano L. Cytogenetic analysis of Astyanax laticeps (Cope, 1894) (Ostariophysi: Characidae) from the laguna dos Patos system. Neotrop Ichthyol. 2009; 7(4):601-05.

Silva AM, Vizzotto PC, Becker QMC, Castro RJ. Karyotype description of three sympatric species of Astyanax (Characiformes, Characidae). Chromosome Society . 2012; 15(1-2):27-30.

Silva DM, Pansonato-Alves JC, Utsunomia R, Daniel SN, Hashimoto DT, Oliveira C, Porto-Foresti F, Foresti F. Chromosomal organization of repetitive DNA sequences in Astyanax bockmanni (Teleostei, Characiformes): dispersive location, association and co-localization in the genome. Genetica. 2013; 141(7-9):329-36.

Souza IL, Moreira-Filho O. Cytogenetic diversity in the Astyanax scabripinnis species complex (Pisces, Characidae). I. Allopatric distribution in a small stream. Cytologia. 1995; 60(1):1-11.

Souza IL, Venere PC, Moreira-Filho O. Constitutive heterochromatin and Ag-NOR polymorphisms in the small characid fish Astyanax scabripinnis (Jenyns, 1842). Cytologia. 2007; 72(1):63-69.

Sumner AT. A simple technique for demonstrating centromeric heterochromatin. Exp Cell Res. 1972; 75(1):304-06.

Tagliacollo VA, Britzke R, Silva GSC, Benine R. Astyanax pirapuan: a new characid species from the upper Rio Paraguay system, Mato Grosso, Central Brazil (Characiformes, Characidae). Zootaxa. 2011; 2749(1):40-46.

Tenório RCCO, Vitorino CA, Souza IL, Oliveira C, Venere PC. Comparative cytogenetics in Astyanax (Characiformes: Characidae) with focus on the cytotaxonomy of the group. Neotrop Ichthyol. 2013; 11(3):553-64.

Vicari MR, Noleto RB, Artoni RF, Moreira-Filho O, Bertollo LAC. Comparative cytogenetics among species of the Astyanax scabripinnis complex. Evolutionary and biogeographic inferences. Genet Mol Biol. 2008a; 31(1):173-79.

Vicari MR, Artoni RF, Moreira-Filho O, Bertollo LA. Colocalization of repetitive DNAs and silencing of major rRNA genes. A case report of the fish Astyanax janeiroensis. Cytogenet Genome Res. 2008b; 122(1):67-72. 
